\title{
THE IMMATURE STAGES OF Paramallocera hirta KIRBY, 1818 (COLEOPTERA: CERAMBYCIDAE: ELAPHIDIONINI)
}

\author{
MORELLI, E. ${ }^{1}$, SANCHEZ, A. ${ }^{2}$ and BIANCHI, M. ${ }^{2}$ \\ ${ }^{1}$ Sección Entomología, Facultad de Ciencias, Iguá, 4225, Montevideo, 11400, Uruguay \\ ${ }^{2}$ Protección Forestal, Facultad de Agronomía, Avda. Garzón, 780, Montevideo, 12900, Uruguay \\ Correspondence to: Enrique Morelli, Sección Entomología, Facultad de Ciencias, \\ Iguá, 4225, Montevideo, 11400, Uruguay, e-mail: emorelli@fcien.edu.uy \\ Received December 9, 2003 - Accepted March 18, 2004 - Distributed February 28, 2006
}

(With 13 figures)

\begin{abstract}
Last instar larva and pupa of Paramallocera hirta Kirby, 1818 are described and illustrated based on specimens reared in the laboratory from neonate larvae on Eucalyptus globulus ssp. globulus logs and on an artificial diet. Characteristics of possible diagnostic value are also presented in this paper.
\end{abstract}

Keywords: Coleoptera, Cerambycidae, Elaphidionini, Paramallocera, larva, pupa, taxonomy, morphology, Uruguay.

\section{RESUMO}

\section{Estágios imaturos de Paramallocera hirta Kirby, 1818}

Neste trabalho, se descrevem a larva do último instar e a pupa do Paramallocera hirta Kirby, 1818, com base em espécimes criados em laboratório a partir de larvas neonatas em toras de Eucalyptus globulus ssp. globulus e com uma dieta artificial. Apresentam-se, também, características com possível valor diagnóstico.

Palavras-chave: Coleoptera, Cerambycidae, Elaphidionini, Paramallocera, larva, pupa, taxonomia, morfologia, Uruguai.

\section{INTRODUCTION}

Paramallocera hirta is a native cerambycid which was first detected attacking Scutia buxifolia Reissek (Rhamnaceae) "coronilla" in 1941, and was recently found attacking Eucalyptus grandis W. Hill ex Maiden in Tacuarembó and Rivera Departments (Uruguay). This beetle was also found to cause damage in E. globulus Labillàrdíere ssp. globulus Kirk in Lavalleja Department (Zajciw \& Ruffinelli, 1962; Ruffinelli, 1967; Monné, 1970; Monné et al., 2002). In Brazil, this species was detected on branches and logs of Eucalyptus spp. L' Herit (Myrtaceae) (Moraes \& Berti Filho, 1974; Berti Filho, 1985). Females generally lay isolated eggs on the bark surface. Neonate larvae burrow through the bark and begin to feed subcortically. As they develop, the larvae burrow wider, deeper and irregular galleries. Mature larvae are approximately $21 \mathrm{~mm}$ in length, with an elongated subcylindrical shape, a milky white tegument and head deeply invaginated into the prothorax. The upper third of the pronotum presents bands of ferruginous setae; the abdomen is extended, having dorsally and ventrally whitish glabrous ampullae. The mature larvae bore obliquely into the xylem, where they pupate at a depth of several centimeters from the surface. Pupa exarate with milky white tegument, ventrally glabrous, dorsal surface of the protorax and abdominal segments have spiniform setae. Finally, the adult emerges from a hole it bores through the bark. 
This study contributes to the body of knowledge about a group of boring larvae that attack Eucalyptus spp. in Uruguay.

\section{MATERIAL AND METHODS}

P. hirta was reared in the laboratory on E. globulus ssp. globulus logs. Neonate larvae were inoculated on logs, which were kept in an environmentally controlled chamber $\left(25 \pm 2{ }^{\circ} \mathrm{C}\right.$, photoperiod 12:12 h. L:D) to obtain mature larvae. The pupal stage was very difficult to obtain following this method, so some neonate larvae were reared on a modified artificial diet (Iglesias et al., 1989; Bianchi et al., 2003).

The characteristics used to describe mature larva and pupa were based on Duffy (1960); Penteado-Dias (1982); Costa et al. (1988) and Stehr (1991).

\section{RESULTS}

\section{Description of the last instar larva (Figs. 1-11)}

Extended body with parallel borders and milky white tegument (Fig. 1). Total length $21 \pm 1.5 \mathrm{~mm}, \mathrm{n}=8$. Head in dorsal view rather broad (Fig. 2). Maximum head width $4.38 \pm 0.2 \mathrm{~mm} \mathrm{n}=8$. Front margin shorter and rather sinuous, with long slender light brown setae, with 4 very long conspicuous central setae, two on each side of the median suture. Epicraneal area smooth, front region regular with white, coarse, slightly transversal area, with a clear dark brown band bearing a row of median setae. Antennae with 3 segments. Under the antennae there are 2 ventral-lateral ocelli on each side. Clypeus narrow and light brown. Labrum (Fig. 4) quadrangular with round external margin, with a row of long setae, $4-6$ short thick setae in the central area; tegument transversally and slightly striated, with abundant striation on anterior $2 / 3$.

Epipharynx (Fig. 5) with a group of 12-14 very long thin setae which extend from the middle of the epipharynx to the external margin. Hypostoma (Fig. 3) laterally and slightly striated, anterior and lateral margins ferruginous brown and weakly sclerotized. Mandible (Figs. 9, 10) symmetric, massive, cuneiform with broad base; 6 slender external setae developed at the base of the mandible; incisive region very strong, broad with sharp edges; molar region with smooth border and large rough surface that arises on the incisive molar edge. Maxilla (Fig. 8) with transversal cardo and stipe very broad and setose. Maxillar trapezoidal lobe with a row of long setae on the upper border. Labium (Fig. 6) with mentum broad and short, with 3 ventral setae on each side, submentum setose. Labial palpi bi-segmented, pubescent and the last palp thinner and longer than the other. Prothorax more conspicuous than the other thoracic segments. Pronotum (Fig. 7) width $7.5 \mathrm{~mm}$ and length $2.5 \mathrm{~mm}$, with round margins. Upper and lateral margins pubescent. Anterior setae of the pronotum short and arranged in 1 or 2 intercalated rows, setae of the lateral margins longer and scattered. These setose areas are located in regions where the tegument is light brown, but interrupted by characteristic discolored areas and they are followed by a broad band of large setae. Abdomen with ten segments, quadrangular, sub-equal with irregular margins. General abdominal chaetotaxy slight and long. Ampullae whitish, glabrous, rugged and irregularly located dorsally on segments III-VII and ventrally on segments III-VIII. Spiracles with peritreme thin, pale and broadly oval; mesothoracic spiracle larger than the abdominal ones; abdominal spiracles present on segments I-VIII. Last segment smaller, semi-quadrangular with 3 very long, conspicuous brown setae located at each side (Fig. 11).

\section{Description of the pupa (Figs. 12, 13)}

Pupa exarate, milky white. Total length about $20 \mathrm{~mm}$. Pronotum quadrangular, maximum width $4.0 \mathrm{~mm}$ and maximum length $4.9 \mathrm{~mm}$; tegument transversally striated with two important lateral tubercles. Central region of the metanotum with a group of 6-8 spiniform setae. Mesothoracic podotecas protected behind the pterotecas. Dorsal surface of the I-VI segments wiht distinctive short spiniform setae arranged in a C-shaped line and dorsal surface of the segments VII-VIII with irregularly distributed spiniform setae. Surface of the ventral tegument glabrous (Fig. 13).

\section{DISCUSSION}

The Elaphidionini is one of the most generically diverse tribes in the family and ranges from Canada to South America and the West Indies. This group has had a long, confusing taxonomic 


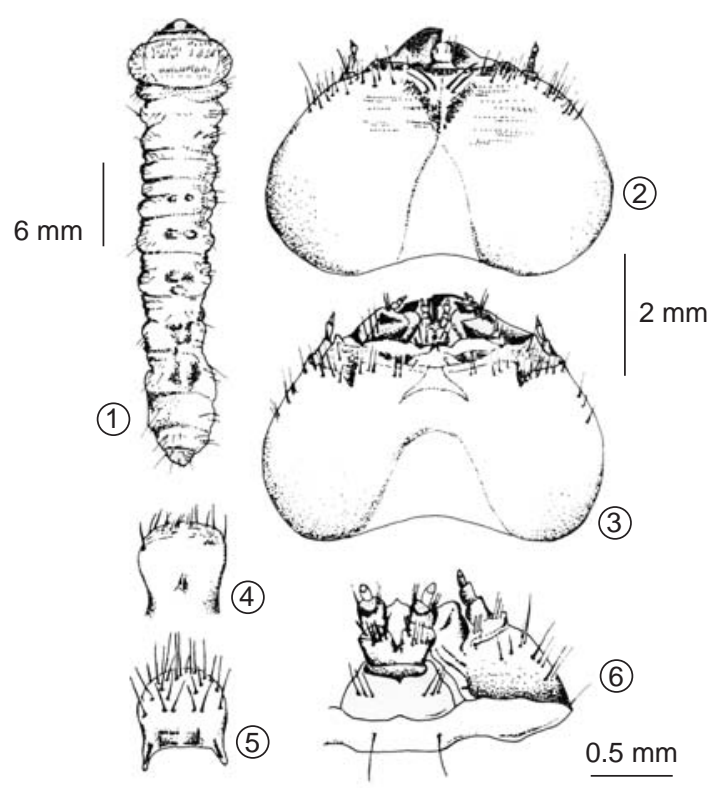

Figs. 1-6 - Paramallocera hirta: 1) larva, dorsal view; 2) head dorsal view; 3) head, ventral view; 4) Labrum; 5) epipharynx; and 6) Labium, ventral view and left maxilla.

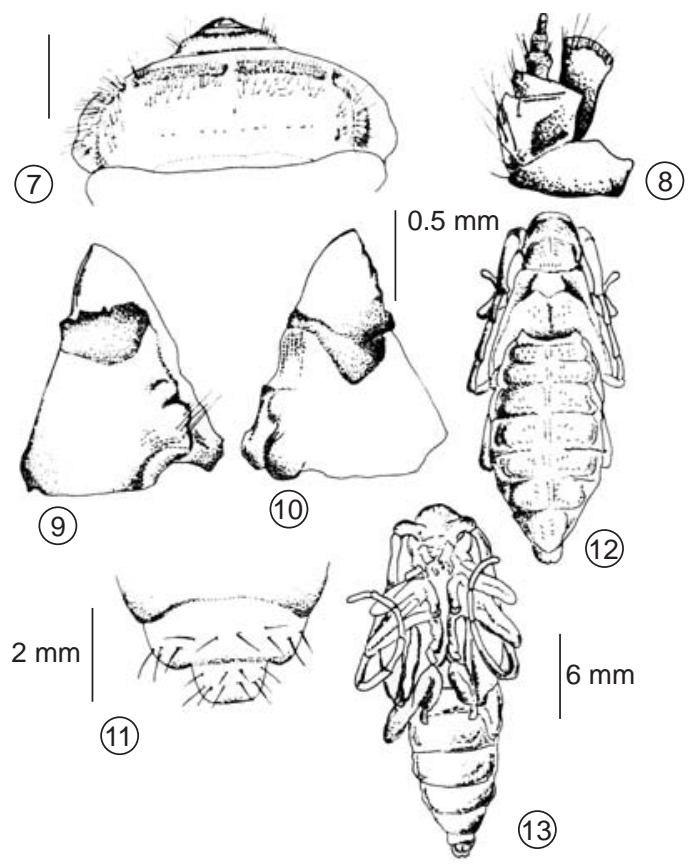

Figs. 7-13 - Paramallocera hirta: 7) Pronotum; 8) left maxilla, dorsal view; 9) Mandible dorsal view; 10) Mandible ventral view; 11) Last abdominal segments, ventral view; 12) pupa, dorsal view; and 13) pupa, ventral view. Scale line in mm.

history, and generic concepts and identity have been unstable (Lingafalter, 1997).

Knowledge about the ontogeny of the Paramallocera species is equally scarce (Fonseca-
Gessner, 1990). Thus, the number and location of the larval abdominal ampullae, ocellar design and pupa chaetotaxy described here are features that may help to characterize the genus. Table 1 compares 
TABLE 1

Larval and pupal anatomical characteristics of Phoracantha recurva, Phoracantha semipunctata, Eurymerus eburioides and Paramallocera hirta.

\begin{tabular}{|l|l|l|l|l|}
\cline { 2 - 5 } \multicolumn{1}{c|}{} & \multicolumn{4}{c|}{ Cerambycid species } \\
\hline \multicolumn{1}{c|}{ Larval charact. } & \multicolumn{1}{c|}{ P. recurva } & \multicolumn{1}{c|}{ P. semipunctata } & \multicolumn{1}{c|}{. . hurioides } & \multicolumn{1}{c|}{ hita } \\
\hline Supraocelar chaetotaxy & 5 setae & 7 setae & 8 setae & $12-14$ setae \\
\hline Ocelli & single & single & single & Double \\
\hline Abdominal ampullae & absent & absent & absent & Present \\
\hline $\begin{array}{l}\text { Distinctive setae on } \\
\text { segment X }\end{array}$ & 4 slender setae & 2 setae & $24-28$ setae & 6 setae \\
\hline
\end{tabular}

\section{Pupa characteristics}

\begin{tabular}{|l|l|l|l|l|}
$\begin{array}{l}\text { Abdominal dorsal } \\
\text { chaetotaxy }\end{array}$ & $\begin{array}{l}\text { I-IV irregular rows of } \\
\text { spinifor setae. } \\
\text { V-VIII single row. }\end{array}$ & $\begin{array}{l}\text { I-III irregular rows of } \\
\text { spinifor setae. } \\
\text { IV-V pair of irregular } \\
\text { rows. } \\
\text { VI-VIII single row. }\end{array}$ & $\begin{array}{l}\text { Irregular rows of } \\
\text { spinifor setae on } \\
\text { segments I-VII }\end{array}$ & $\begin{array}{l}\text { I-VI spiniform setae } \\
\text { on a C-shaped line. } \\
\text { VII-VIII spiniform } \\
\text { setae irregularly } \\
\text { distributed }\end{array}$ \\
\hline
\end{tabular}

the main larval and pupal characteristics of 3 other species of cerambycids that attack Eucalyptus in Uruguay (Morelli et al., 2002; Morelli et al., in press) with $P$. hirta.

Acknowledgments - This work was partially funded by the Instituto Nacional de Investigación Agropecuaria (INIA Uruguay). We thank Ing. Agr. Rafael Escudero for his assistance with the field work.

\section{REFERENCES}

BERTI-FILHO, E., 1985. Insects associated to Eucalypt plantations in Brazil, pp.162-178. In: IUFRO WP. S2. 07.07. Protection of Forests in the Tropics. (24-30 Nov. 1985, Curitiba). Noxious insects to Pine and Eucalypt plantations in the Tropics. Curitiba. Universidade Federal do Paraná.

BIANCHI, M., ESCUDERO, R., MORELLI, E. \& SÁNCHEZ, A., 2003, Biología y tácticas para el control integrado de Eurymerus eburioides A. Serville y de Paramallocera hirta Kirby (Col: Cerambycidae) en Uruguay. INIA LIA 052. 9p.

COSTA, C., VANIN, S. A. \& CASARI-CHEN, S. A., 1988, Larvas de Coleoptera do Brasil. Museu de Zoologia, Universidade de Sao Paulo: FAPESP. 282p., 165 PL.

DUFFY, E., 1960, A monograph of the immature stages of neotropical timber beetles (Cerambycidae). British Museum. London 327p., XIII.

FONSECA-GESSNER, A., 1990, Revisão Taxonómica do gênero Paramallocera Aurivillus, 1912 (COLEOPTERA, CERAMBYCIDAE, CERAMBYCINAE, SPHAERIONINI). Revista Brasileira de Entomologia, 34(4): 817-856.

IGLESIAS, C., NOTARIO, A. \& BARAGAÑO, J. R., 1989, Evaluación de las condiciones de cría y datos bionómicos de coleópteros lignícolas de tocón de pino. Bol. San. Veg. Plagas, 15: 9-16.

LINGAFELTER-STIVEN, W. ,1997, Morphology and phylogeny of genera of Elaphidionini Thomson, 1864 (Coleoptera: Cerambycidae). www.nal.usda.gov/ttic/ tektran/data/000008/23/0000082394.htm.

MONNÉ, M., 1970, Fauna de los Coleópteros del Uruguay. 216p. Tesis Ing. Agr. - Fac. de Agronomía, Montevideo, Uruguay.

MONNÉ, M., BIANCHI, M, SANCHEZ, A., \&, ESCUDERO, R., 2002, Cerambícidos (Coleoptera) que atacan Eucalyptus globulus y Eucalyptus grandis en Uruguay. Agrociencia., 6(1): 63-68.

MORAES, G. J. \& BERTI-FILHO, E., 1974, Coleobrocas que ocorrem em essencias florestais. IPEF 9. Piracicaba, SP.

MORELLI, E., BIANCHI, M., \& SANCHEZ, A., 2002, The immature stages of Phoracantha recurva Newman, 1842 and Phoracantha semipunctata Fabricius, 1775 (Coleoptera: Cerambycidae) and a key to larvae of these species. Brazilian Journal of Biology, 62(4B): 1-8.

MORELLI, E., BIANCHI, M., and SANCHEZ, A., 2005, The immature stages of Eurymerus eburioides Audinet -. Serville, 1833 (Coleoptera: Cerambycidae: Ectenessini). Braz. J. Biol., 65(1): 97-100

PENTEADO-DIAS, A. 1982. Callipogon (Navosoma) luctuosum (Schoenherr, 1817): notas sobre a biologia, descriçoes de larva e pupa (Coleoptera, Cerambycidae). Revta Bras. Ent., Sao Paulo. 26(3-4): 219-224. 25 figs.

RUFFINELLI, A., 1967, Insectos y otros vertebrados de interés forestal. Silvicultura (Uruguay), 25: 3-79.

STEHR, F. W., 1991, Immature insects. F. W., Stehr (de.), Kendall/Hunt Publishing Company U. S. A. $2^{\circ}$ vol. 975 p.

ZAJCIW, D. \& RUFFINELLI, A. 1962. Fauna de los cerambícidos del Uruguay. Uruguay. Fac. Agron. 60: 89p. 